\title{
SWOT Analysis in a Maritime Higher Education Institution: Strategic Planning Basis for Institutional Efficiency
}

\author{
Victoria Q. Paraggua \\ Froilan D. Mobo \\ Ronalyn C. Acuavera \\ Leah R. Villavicencio \\ Geraldine C. Pasa \\ Sheena Lee R. Atejera \\ Philippine Merchant Marine Academy/Philippines \\ vqparaggua@pmma.edu.ph \\ fd.mobo@pmma.edu.ph \\ rc.acuavera@pmma.edu.ph \\ lr.villavicencio@pmma.edu.ph \\ gc.pasa@pmma.edu.ph \\ slr.atejera@pmma.edu.ph
}

Received: 13 August 2021; Revised: 02 October 2021; Accepted: 28 December 2021

DOI: http://dx.doi.org/10.37905/aksara.8.1.631-648.2022

\begin{abstract}
Higher education institutions conduct strategic planning to attain their goals and enhance their operations. Aiming for improved institutional efficiency, the Philippine Merchant Marine Academy (PMMA) conducted SWOT analysis to help establish an effective strategic plan. This quantitative-descriptive study, contributes to the understanding of the Strengths, Weaknesses, Opportunities and Threats (SWOT) affecting the operations of PMMA as a maritime higher education institution. Using a Likert Scale survey questionnaire, the data gathered from 767 respondents revealed that deliberate changes must be made to facilitate institutional growth. The PMMA's strengths showed that the academy is meeting its objectives and its weaknesses are primarily process driven issues that need attention. The academy's opportunities are external essentials that provide better chances and options for midshipmen to progress through their academic and training experiences. Most of the respondents agreed that the Academy has threats related to the ongoing COVID-19 pandemic and other future health crisis. To face many challenges brought by the globalization and the pandemic, PMMA has to develop a strategic approach based on the SWOT Analysis leading to improved efficiency. This initiative is meant to institutionalize SWOT analysis at the PMMA and encourage the practice of SWOT analysis in other higher education sectors.
\end{abstract}

Keywords

SWOT Analysis, Strategic Planning, Institutional Efficiency, Maritime Higher Education Institution

\section{INTRODUCTION}

A higher education institution delivers academic programs leading to an academic degree. It could either be non-profit or a profit-based unit and a public or private institution. It is an institution of higher learning which includes universities, polytechnic, agricultural colleges, which specialize in different fields such as engineering, agriculture, medicine, pedagogy, the arts, and economics among others. The benefit of higher education in the 21 st century is not just career-oriented. Being able to develop oneself is priceless, and taking higher education programs helps one do that. Higher education trains students in their chosen field, but it also teaches them to understand complex subjects by helping them develop and master the skill to think analytically, and communicate ideas effectively. Moreover, it also makes students learn 
important soft skills, such as self-discipline, organization, and other work-related skills, helping them become more professional. Evidently, the goal of higher education encompasses a wide variety of elements: public service to society labor; market success; and the development of students' social and critical thinking skills, empathy, and commitment to civic engagement.

There are various pillars for safe and efficient shipping, and one of the most important is the quality of maritime education system, particularly the maritime education at the university level and those guaranteeing seafarers' top rank qualifications in accordance with the Standards of Training, Certification, and Watch keeping (STCW) Convention. (Čampara et al., 2017). The Philippine Merchant Marine Academy (PMMA), a quasi-military and one of the merchant marine academies in the Philippines, is operated by the government of the Philippines. Being the premier maritime institution in the country, PMMA is always aiming for improved institutional efficiency. For some time, the Academy has been conducting strategic planning to improve institutional efficiency so that the major goals of PMMA as a higher education institution will be successfully attained.

Strategic planning is a process wherein leaders of organization find out and establish their vision for the future and determine their organizational goals and objectives. The method also involves establishing the arrangement in which those goals should fall so that the organization will meet its goals and targets. (Pratt, 2016.) Strategic planning provides a sense of direction and outlines measurable goals, which makes it very vital to an organization. It is a tool beneficial for guiding daily decisions and also for assessing advancement and improvement and changing strategies when moving forward. It is about looking forward, beyond the future for the organization, to attain established set of goals. It also includes every step in attaining the organization's objectives and major final outputs. (Jackson, 2021)

Higher education strategic planning helps an institution focus on its success in responding to the changing world. This process aids the institution in determining the opportunities to make a difference and the changes required to do today to be ready for tomorrow. This should involve the effort and participation of the entire campus community_both internal stakeholders (faculty, students, administration, staff, alumni) and external stakeholders (community members and employers). A strategic plan aids in defining what an institution intends to achieve when it comes to their student success objectives and organizational goals. Good planning and communication will ensure that all stakeholders including parents, teachers, administrators, board members and community are all aspiring for the same goals. The creation of high-output teams, proper management of budgetary and time resources, and the consistent monitoring of all progress lead to successful strategic planning. Universities and colleges devote time and effort in strategic plans to assist their institution's direction and differentiate appeal in an often-competitive marketplace of prospective students.

To ensure success in strategic planning, a company should give careful thought to the stated strategic objectives which are backed up with realistic, thoroughly researched, and quantifiable benchmarks for evaluating results. To support the successful implementation of a university strategic plan, the various levels of the strategic planning system should be clearly aligned with its goals and objectives, and the heads should keep a focus on the strategic plan's wide-ranging goals. 
Aside from the helpful tips and techniques, another successful way of strategic planning is by doing SWOT (strengths, weaknesses, opportunities, and threats) analysis. This is a process for recognizing and examining internal strengths and weaknesses and external opportunities and threats that help develop strategic objectives and affect the existing and future operations. SWOT analysis is a framework for determining and investigating the strengths, weaknesses, opportunities and threats of an organization which is what makes up the SWOT acronym. This tool, which is a source of data for strategic planning, uses a planning approach that assists organizations in establishing a strategic plan to attain goals, enhance operations and keep the business significant. (White, 2018)

The main aim of SWOT analysis is to help organizations to be more aware of the factors affecting a business decision by scrutinizing the internal and external factors that can influence the feasibility of a decision. SWOT Analysis is a simple but valuable framework for evaluating one's organization's strengths, weaknesses, opportunities, and threats because it helps to build on what should be done well, in order to address what is lacking, to minimize risks, and to take the greatest possibility for success. This is also beneficial in getting and understanding the competitors, which can give the insights needed to craft a comprehensible and successful competitive position. SWOT analysis are very advantageous for it contributes to building strengths, helping strategic planning through the information provided, helping to eliminate threats and capitalizing on opportunities as well as identifying skills. Thus, through a SWOT analysis, an institution can link resources and capabilities to the conditions and circumstances in which it functions. (Vitan, 2017)

This study focused on analyzing the strengths, weaknesses, threats and opportunities of the Philippine Merchant Marine Academy as basis for strategic planning towards institutional efficiency. Specifically, the study sought to answer the following questions:

1. What is the PMMA institutional strengths as perceived by the respondents in the following areas:
a. Management;
b. Personnel;
c. Academics;
d. Support Services;
e. Operations; and
f. External Relations?

2. What is the PMMA's distinct excellence as perceived by the respondents?

3. What are the potential opportunities for PMMA as perceived by the respondents?

4. What is the level of possibility that the identified external factors become a threat to PMMA?

5. What are the recommendations to improve the institutional efficiency of the Academy?

The result of this study contributes to the understanding of strengths, weaknesses, opportunities and threats affecting the operations of a maritime higher education institution, specifically the Philippine Merchant Marine Academy. The data gathered could be utilized in the strategic planning in the Academy. The study intends to encourage the practice of SWOT analysis in higher education sectors and it is expected 
that the results of the study would be worthwhile in the decision making and strategic planning of higher education institutions.

SWOT Analysis, according to Gurel \& Tat (2017), is a tool used for strategic planning and strategic management in organizations, which can be used effectively to build organizational and competitive strategy. In agreement with the System Approach, organizations consist of various sub-systems that are in collaboration with their environment. They added that an organization exists in two environments, one being in itself and the other being outside. Examining these two environments is a requirement for strategic management - and the process is termed SWOT Analysis.

In his study, Shvardak (2021) emphasized that the implementation of strategic planning needs to carry out a SWOT analysis, for it is a functional and reasonable tool for evaluating the condition of the problem and the management state in higher education. SWOT analysis gives the chance: (1) to organize the problems; better understand the organization of resources necessary in improving the actions and the future development of the institution; (2) monitor the general condition of the external and internal environment; (3) recognize and explore new abilities faster than competitors do; (4) select the ideal path of development and prevent threats; make upto-date and clever decisions on the execution of educational procedures.

According to Tuncay (2015), the resources of a public institution will be actively and effectively utilized if status analyses of the physical, human and economic resources will be performed and strategic management will be applied effectively. Organizations which are lacking strategic points of view cannot have the visualization to create their goals for they cannot clearly define the purpose of their presence. Further, he mentioned that self-evaluation of organizations can be accomplished through strategic management by presenting and examining its strengths and weaknesses. Thus, organizations can see themselves as a whole and can realize accurately which goals they can and/or cannot achieve. In this manner, the organization can reasonably direct the personnel to act in accordance with their aims.

In the research of Wang et. al (2018) where SWOT analysis method was used to compare the advantages and disadvantages and opportunities and threats between old and new campuses of a university in China, the results suggest that in the co-occurrence of strengths, weaknesses, opportunities and threats, new and old campuses should implement different development strategies to prevent continuous decline of students in the future. For the old campus, employing its integral advantages and thus changing the crowded space is the most significant feature of different development approaches. For the new campus, grabbing the external opportunities to tamp the campus culture is the best solution. Supposing that old and new campuses cannot co-exist due to decrease of students, the prime concern should be given to protecting old campuses.

After a comparative analysis was performed on the basis of the differentiations among the Higher Education Institutions (HEIs) in China, at different levels and of different types, Hu et.al (2018) found out that: (1) the surveyed HEIs attributed great significance to a five-year plan; however, there are differences in terms of framing an expert plan and a medium- and long-term plan; (2) the HEIs at the higher level are more determined in their corresponding undertakings; (3) vocational colleges and private HEIs concentrate more on the roles of students, alumnus, and external experts; and (4) vocational colleges and private HEIs appear to be more task-oriented compared with HEIs at other levels and of other types. 
In their research, Aisyi \& Zulkarnain (2020) gave a strategic suggestion to collect several plans that will be developed by coordinating with the government. They emphasized that careful planning definitely leads to best results, therefore, it is essential to have good planning to know how to make sound plans according to the direction of the government and considering the importance of mutual perception, mutual openness, and mutual respect. The findings of the study of George et. al (2019) suggest that strategic planning should be part of the standard managerial approaches in contemporary organizations. Further, they mentioned that strategic planning has a positive, moderate, and significant impact on organizational performance in the private and public sectors, across international settings. The study of Khalid et. al (2017) proposed SWOT analysis for the universalization of higher education in Pakistan, which shows the internal and external influences that have positive or negative impact to the higher education system. Moreover, the study suggests vital recommendations and activities useful for fast universalization process. The study is suitable for the higher education institutions to gain understanding on the important requirements of internationalization as well as it is beneficial for policy makers in developing long-term plans.

Amos et al. (2021) emphasized that for enhancement of operational efficiency, institutions should identify and build technological infrastructure for academic delivery, address the psychology and mental health of academic staff during pandemic in order to prevent disruption to institution's activities/services. Teleworking and teleschooling strategies in different contexts could be considered as innovative means of deploying technology in supporting institutions' continuity and sustaining social connection within the academic families and communities. Adepoju \& Okunola (2018) summarized their paper proposing for a shift in the paradigm of the processes and activities of Vocational Technical Education program in the educational institutions in Nigeria to improve efficiency by utilizing SWOT analysis which has been an effective and useful tool for decision making as new vocational and technical education program are planned.

By comparing some of the items in the SWOT analysis with the current situation at the Maritime Department of the University of Dubrovnik in Croatia, it was reported in the study of Campara et al. (2017) that Special Education Program (SEP) does not significantly affect the quality of the university Maritime Education and Training (MET) system. Due to the increasing level of interest for maritime professions, the number of students has been greater than in recent years.

Based on the SWOT analysis for the development of the Sekolah Tinggi Teknologi Angkatan Laut (STTAL) or Indonesian Naval Technology College curriculum, Apriyani et. al (2019) stressed that the Vision, Mission, STTAL Objectives and the present and future challenges of the industrial revolution 4.0. faced by STTAL, are the basis of the strategic goals that serve as a reference indicator for achieving strategic plan. The STTAL curriculum development scheme objectives become beneficial in developing strategic factors based on strengths, weaknesses, opportunities and threats. Vitan (2017) concluded her study stating that each institution has a goal performance in the field which is viewed in different ways by each individual depending on the object of activity and the purpose tracked. The performance of pre-university education institutions is similarly related to quality and results. The SWOT analysis of the pre-university education system allows a summary of the quality of the actions of 
these institutions, as well as the performance in the resources management and the modern systems implementation required for the strategic and decision-making management.

Over-all, these presented studies emphasized the importance of SWOT analysis in performing strategic planning. It serves as the baseline to ensure that the plan to be laid will be responsive to the needs of the institution, which entails higher chance of improvement and success.

\section{METHOD}

The study used a quantitative-descriptive research design to assess and analyze the Strengths and Weaknesses or internal factors and attributes, and Opportunities and Threats or external factors and attributes of the Philippine Merchant Marine Academy. This is a design that identifies the strong and weak aspects of the organization by examining the elements in the environment while the opportunities and strengths are determined as the elements outside its environment. The SWOT Analysis is the basis for strategic planning and to balance the Academy's strengths and weaknesses in the light of environmental opportunities and threats.

The variables of the study are as follows: (a) demographic profile of the respondents, (b) perception on the institutional strengths and weakness of the Academy in the following areas: Management/Personnel, Academics, Support Services, Operations, External Relations, (c) perception on the distinct excellence of the academy, (d) perception of the potential opportunities in the near future, (e) perception of possible threats in the academy and; (f) other potential areas that needs improvement.

The respondents of the study are the cadet/cadettes and the employees in the Academy. A total of 604 cadet/cadette composed of mostly male respondents participated in the study. Furthermore, a total of 146 employees and 17 more (unidentified) respondents participated through the printed survey form.

Convenience sampling was used. This method is done by collecting research data based on the availability and willingness of the respondents to take part in the survey. The instrument used is a printed survey questionnaire administered to all employees and cadets of the Academy. As part of the preventive measures and to avoid close contact and chances of contracting COVID-19, the researchers prepared drop boxes for survey responses and placed them outside the respective buildings inside the academy. The availability of the drop boxes ensures that the survey questionnaires were secured and cannot be tampered.

The survey questionnaire consists of three parts: (1) demographics; (2) perception on strengths, weaknesses, opportunities, and threats; and (3) other comments/suggestions. It used a Likert Scale to measure the respondents' insight. To identify the perception of the respondents on the strengths and weaknesses in various areas and the distinct excellence of PMMA, the responses were scaled from (1) strongly disagree, (2) disagree, (3) agree and (4) strongly agree. The perception of the respondents to the potential opportunities for PMMA was scaled from (1) very unlikely, (2) unlikely, (3) likely and (4) very likely. Moreover, the possible threats to PMMA were rated from (1) not applicable, (2) low, (3) average and (4) high.

With the restriction of movement and the need for social distancing, the researchers strictly adhered to the guidelines and protocols set by the Academy in the 
collection of data.

The following procedures were followed in gathering data for the study.

a. The DRDE laid a plan for a research-based SWOT analysis and sought approval from the concerned heads/departments.

b. The survey instrument was distributed to the target respondents.

c. For the collection of floated questionnaires, drop boxes were placed outside the buildings inside the Academy.

d. The collected data was processed and analyzed using Tables and Microsoft Excel. The Mean were also identified. The scale intervals were interpreted as follows:

\begin{tabular}{|c|l|}
\hline Range & Qualitative Interpretation \\
\hline $3.26-4.00$ & Strongly Agree \\
\hline $2.51-3.25$ & Agree \\
\hline $1.76-2.50$ & Disagree \\
\hline $1.00-1.75$ & Strongly Disagree \\
\hline
\end{tabular}

\section{RESULTS AND DISCUSSION}

\section{Results}

Presented in this section are the results of the study, using the quantitativedescriptive research design. Results are discussed in reference to the aims of the study: to assess and analyze the Strengths and Weaknesses or internal factors and attributes, and Opportunities and Threats or external factors and attributes of the Philippine Merchant Marine Academy; and also, to contribute understanding of strengths, weaknesses, opportunities and threats affecting the operations of a maritime higher education institution. Through the descriptive analysis of the data gathered, the study has the following findings:

As shown in Table 1, a total of seven hundred sixty-seven (767) respondents composed of mostly male cadets answered the SWOT survey questionnaire distributed to all PMMA employees and cadets/cadettes.

Table 1.

Profile of Respondents

\begin{tabular}{lcc}
\hline Category & Count & \% \\
\hline Teaching Staff & 39 & $5.08 \%$ \\
Non-Teaching Staff & 107 & $13.95 \%$ \\
Cadet/Cadette & 604 & $78.75 \%$ \\
No Response & 17 & $2.22 \%$ \\
\hline TOTAL & $\mathbf{7 6 7}$ & $\mathbf{1 0 0 . 0 0 \%}$ \\
\hline Sex & & \\
Male & 628 & $81.88 \%$ \\
Female & 98 & $12.78 \%$ \\
No Response & 41 & $5.35 \%$ \\
\hline TOTAL & $\mathbf{7 6 7}$ & $\mathbf{1 0 0 . 0 0 \%}$ \\
\hline
\end{tabular}

\section{Institutional Strengths and Weaknesses}


Figure 1 summarizes the strengths, weaknesses, opportunities, and threats of the Academy. From the forty-four (44) items listed, the respondents were asked about the extent of their agreement/disagreement on the PMMA institutional strengths in terms of management, personnel, academics, support services, operations, and external relations. Of the responses, the top five (5) with the highest ratings were perceived as the Academy's strengths whereas the bottom five (5) was considered its weaknesses. Out of eleven (11) identified potential opportunities (see Table 3), five (5) items were considered as the most potential opportunities.

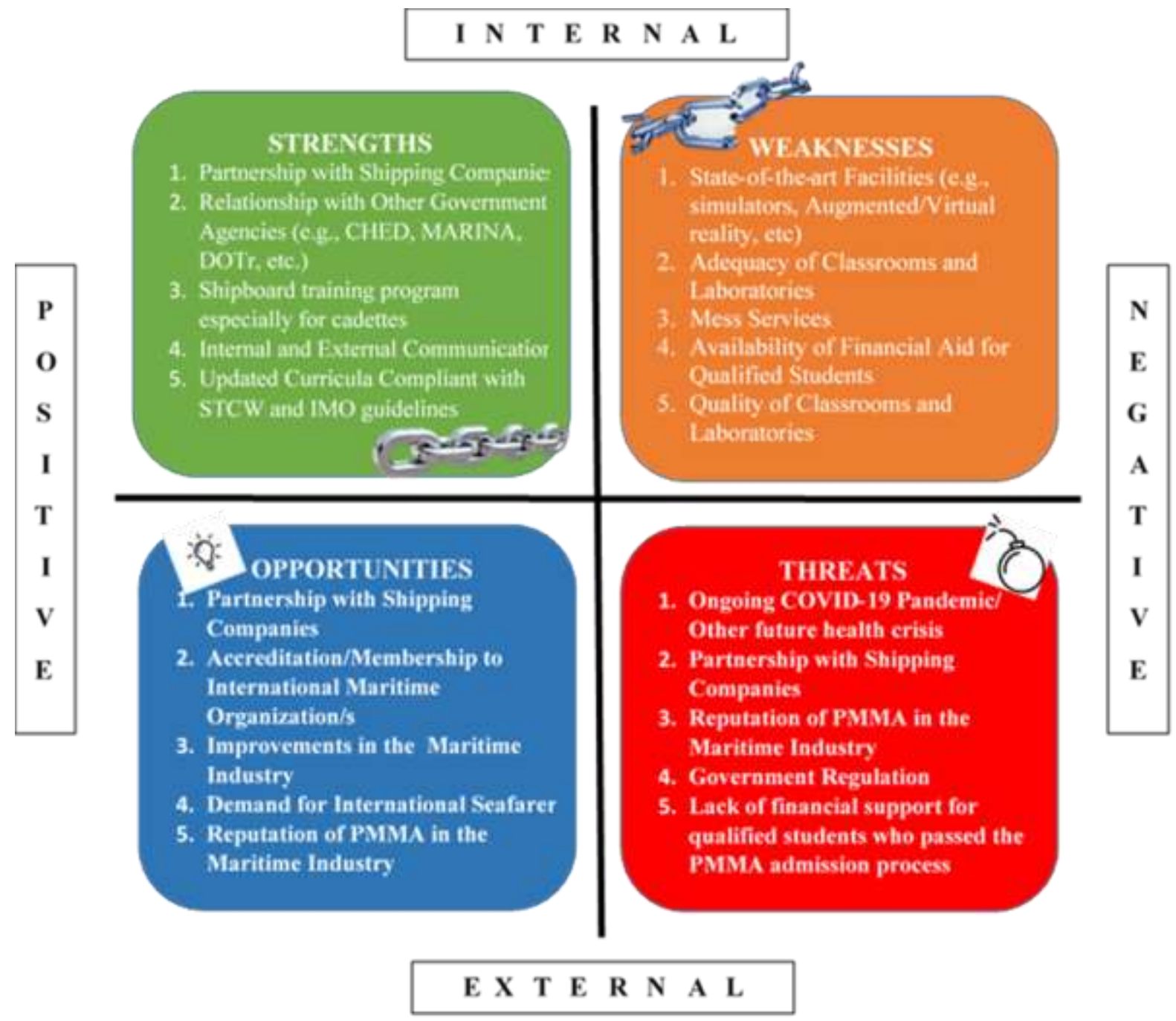

Figure 1. Summary of SWOT Results

\section{Perceived Distinct Excellence of PMMA}

Table 2 provides the eight perceived areas where PMMA is of distinct excellence, of which again its Shipboard Training Program ranks number 1. Table 2

Perceived Distinct Excellence of PMMA by Respondents 


\begin{tabular}{lcccccccc}
\hline $\begin{array}{l}\text { PMMA is distinctly excellent } \\
\text { in... }\end{array}$ & SD & D & A & SA & NR & MEAN & RANK & QI \\
\hline $\begin{array}{l}\text { 1. Shipboard Training } \\
\text { Program }\end{array}$ & 12 & 57 & 336 & 218 & 144 & 3.22 & 1 & Agree \\
$\begin{array}{l}\text { 2. Networking/ Partnership } \\
\quad \text { with External Stakeholders }\end{array}$ & 14 & 80 & 399 & 133 & 141 & 3.04 & 2 & Agree \\
3. Training Programs & 16 & 86 & 390 & 136 & 139 & 3.03 & 3 & Agree \\
$\begin{array}{l}\text { 4. Research and } \\
\text { Development }\end{array}$ & 26 & 102 & 387 & 110 & 142 & 2.93 & 4 & Agree \\
$\begin{array}{l}\text { 5. Quality of Education } \\
\text { 6. Student Support }\end{array}$ & 25 & 128 & 353 & 121 & 140 & 2.91 & 5 & Agree \\
$\quad$ Services/Programs & 25 & 121 & 372 & 108 & 141 & 2.90 & 6 & Agree \\
7. Management Style & 33 & 139 & 375 & 79 & 141 & 2.80 & 7 & Agree \\
\hline \multicolumn{1}{c}{ OVER-ALL MEAN } & & & & $\mathbf{2 . 9 8}$ & & Agree \\
\hline
\end{tabular}

\section{Potential Opportunities}

PMMA's opportunities (Table 3) are external essentials that provide PMMA with areas of focus that will build on current strengths and provide improved opportunities and options for midshipmen/women to progress through their academic and training experiences.

Table 3

Potential Opportunities for PMMA as Perceived by Respondents

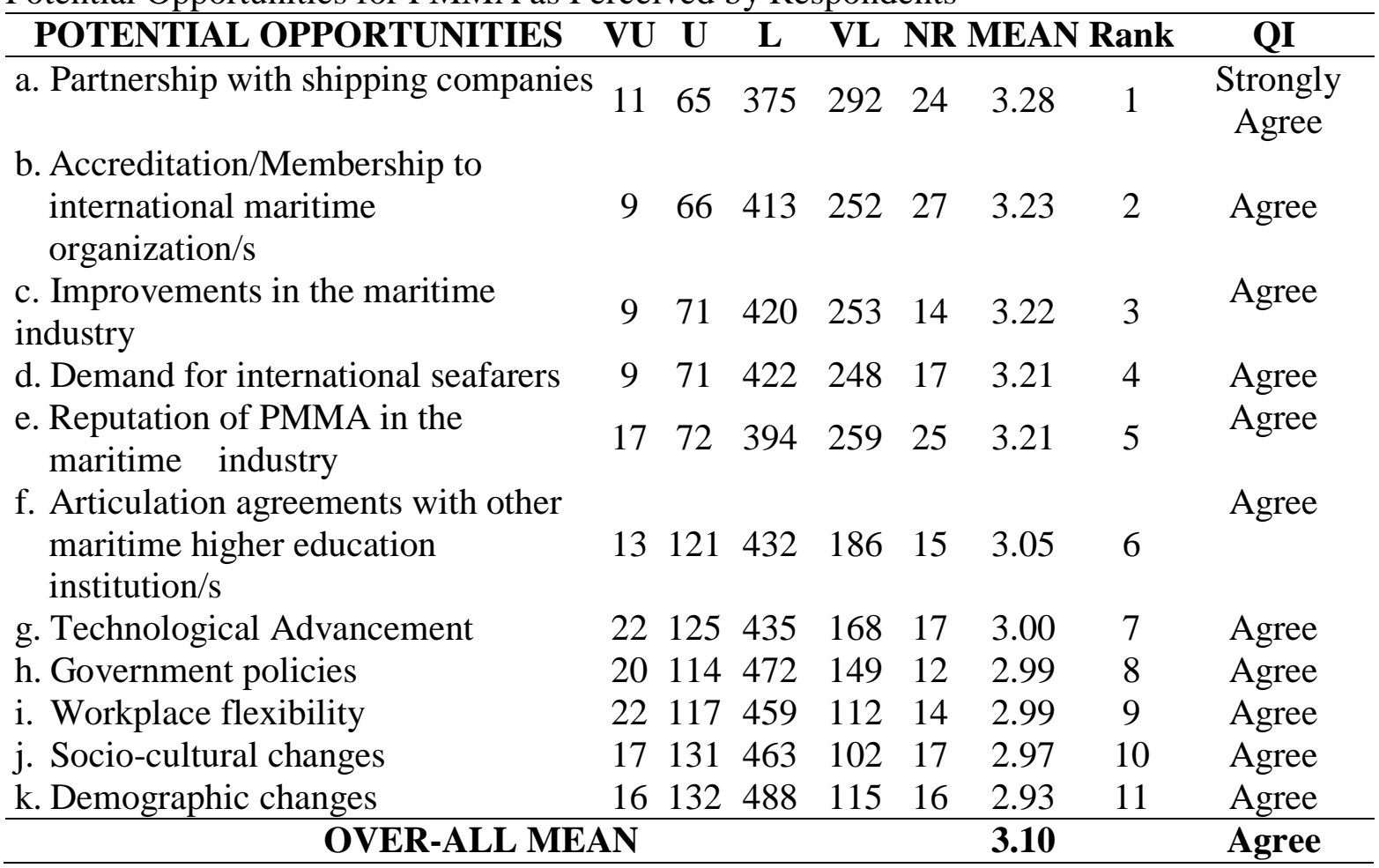

\section{Potential Threats}


PMMA's threats (Table 4) are external factors that must be understood and managed as PMMA implements improvements, new initiatives and continuous improvement processes.

Table 4

Potential Threats for PMMA as Perceived by Respondents

\begin{tabular}{|c|c|c|c|c|c|c|c|c|}
\hline POTENTIAL THREATS & NA & LOW & $\begin{array}{l}\text { AVERAG } \\
\text { E }\end{array}$ & HIGH & NR & $\begin{array}{c}\text { MEA } \\
\mathbf{N}\end{array}$ & Rank & QI \\
\hline $\begin{array}{l}\text { a. Ongoing COVID-19 } \\
\text { Pandemic/Other future } \\
\text { health crisis }\end{array}$ & 1 & 144 & 377 & 205 & 27 & 3.04 & 1 & Agree \\
\hline $\begin{array}{l}\text { b. Partnership with shipping } \\
\text { companies }\end{array}$ & 30 & 159 & 338 & 208 & 32 & 2.99 & 2 & Agree \\
\hline $\begin{array}{l}\text { c. Reputation of PMMA in the } \\
\text { maritime industry }\end{array}$ & 31 & 159 & 381 & 160 & 36 & 2.92 & 3 & Agree \\
\hline d. Government Regulation & 19 & 155 & 449 & 113 & 31 & 2.89 & 4 & Agree \\
\hline $\begin{array}{l}\text { e. Lack of financial support } \\
\text { for qualified students who } \\
\text { passed the PMMA } \\
\text { admission process }\end{array}$ & 19 & 209 & 357 & 153 & 29 & 2.87 & 5 & Agree \\
\hline $\begin{array}{l}\text { f. Competition from other } \\
\text { MHEIs }\end{array}$ & 18 & 193 & 402 & 123 & 31 & 2.86 & 6 & Agree \\
\hline $\begin{array}{l}\text { g. Accreditation/membership } \\
\text { requirements }\end{array}$ & 15 & 193 & 427 & 99 & 33 & 2.83 & 7 & Agree \\
\hline h. Economic crisis & 18 & 203 & 402 & 112 & 32 & 2.83 & 8 & Agree \\
\hline i. Natural disasters & 21 & 241 & 383 & 95 & 27 & 2.75 & 9 & Agree \\
\hline OVER-ALL MEAN & & & & & & 2.89 & & Agree \\
\hline
\end{tabular}

Discussion

Institutional Strengths and Weaknesses

PMMA's strengths lie in the fact that it is meeting its aims and objectives, - to lead, as a great specialized professional Academy in the era of internalization of higher education, in securing the country's comparative advantage in the future of global maritime industry. As Tuncay (2015) emphasized, through self- evaluation, organizations can see themselves as a whole and can realize accurately which goals they can and/or cannot achieve. In this manner, the organization can reasonably direct the personnel to act in accordance with their aims. In terms of its strengths, 3 out of 5 were indicators on external relations. First is the partnership with shipping companies, with the mean score of 3.23. PMMA has been supported by multiple shipping companies especially in implementing the mandatory shipboard training program for 2nd class cadets. To date, PMMA has a total of forty-eight (48) partner shipping companies wherein sixteen (16) are with Memorandum of Agreement (MOA), two (2) with Memorandum of Understanding (MOU) and thirty (30) without MOA or MOU. These partnerships with shipping companies ensure the smooth implementation of the Academy's shipboard training program, which is seen as an institutional strength of the Academy. 
Shipboard training is a compulsory requirement and component of the BSMT and BSMarE programs that pertain to the required seagoing service as provided under Regulation 11/1 and Regulation III/1 of the STCW Convention. The Department of Shipboard Training (DST) ensures that all second class (3rd year) cadets are able to undergo a one-year training onboard ocean-going vessels wherein the cadets are provided with the opportunity to use a ship as a sea-going laboratory which also requires them to complete their Training Record Books. Moreover, the respondents perceived Shipboard training program especially for cadettes as another strength of the Academy, with the mean score of 3.05, which ranked 3rd. According to the International Maritime Organization (2019), women represent only 1.2\% percent of the global seafarer workforce as per the BIMCO/ICS 2021 Seafarer Workforce Report. This represents a positive trend in gender balance, with the report estimating 24,059 women serving as seafarers, which is a $45.8 \%$ increase compared with the 2015 report. During School Year 2020-2021, the Class 2022, 200 out of 201 or $99.5 \%$ were able to undergo shipboard training.

The PMMA is constantly and closely collaborating and coordinating with various agencies. Being a higher education institution that complies with the curriculum released by the Commission on Higher Education (CHED) and being regulated by the Maritime Industry Authority (MARINA) as a maritime institution which is under the Department of Transportation responsible for integrating the development, promotion and regulation of the maritime industry in the Philippines, the Academy, with the joint efforts of MARINA and the CHED, developed in 2019, standard program for Bachelor of Science in Marine Transportation (BSMT) and Bachelor of Science in Marine Engineering (BSMarE), which will be implemented by all maritime schools across the country. The Academy also partnered with the Philippine Coast Guard and Philippine Navy for the Cadetship and Scholarship Program of respective agencies. Graduates of PMMA are automatically commissioned in the Philippine Navy and Philippine Coast Guard as Ensign (2LT) (https://www.pmma.edu.ph/admission-process/). Just recently, PMMA and the PCG have signed a MOA that aims to further strengthen the partnership of both institutions in terms of the development of its Human Resources.

Internal and external communications, with a mean of 3.01, are considered to be very important factor that would lead to support and teamwork within the academy and strong partnership especially with shipping companies. Internal communication helps employees in performing their work, and identifying and promptly dealing with the immediate and urgent matters. Special Orders, Memorandum Orders and Circulars are widely disseminated for the information of everyone. Moreover, the Academy is using the MS Outlook/Teams as one of the channels of internal communications. The employees and students were provided business e-mail addresses. Each Department/Unit head scheduled a meeting with their staff to exchange information, plan and coordinate activities regularly or if necessary. For the purpose of better information exchange and activities coordination, the OAS-ATRE launched the use of Google Calendar, while One Drive let the employees access the shared file or documents. Telephone was also provided in each office for internal communication. The Department/Unit Heads, Faculty members and other official regularly receive communication allowance. In addition, PMMA has also partnered with Smart Communications, Inc. to board the PLDT wireless arm's Smart Infocast system, an SMS broadcast solution that will enable PMMA to send out advisories and alerts directly to students, employees, and staff. To date, however, the system has yet to be fully operational. Nonetheless, Smart also turned over Smart Bro LTE Pocket 
WiFi devices that will enable constant communication between and among key management and operations officials as they ensure the smooth conduct of PMMA operations.

External communication with its stakeholders goes both within the Academy and outside of it. Special attention is given to this regardless it is via letter, email, web, telephone or some other way. The Academy has a communication officer and other officers responsible in the external communications. Letters, reports, presentations or web pages were carefully created as these reflect the work and quality of the Academy.

In relation to the Academy's institutional strength on the presence of an updated curricula compliant with STCW and IMO guidelines, in September 2020, the two colleges in the Academy have started implementing a new curriculum which is based on Joint CHED MARINA Memorandum Circular No. 01 Series 2019 entitled Policies, Standards and Guidelines for the Bachelor of Science in Marine Transportation and Bachelor of Science in Marine Engineering Programs. These policies, standards and guidelines implement the shift to learning competency-based standards/outcome- based education which adopts the competencies expected of BSMT and BSMarE graduates according to the STCW Convention, 1978. The faculty are also required to take further higher education in order to effectively facilitate the teaching of the various learner competencies required by the memorandum.

Regarding the PMMA's weaknesses, they are primarily process driven issues that need attention. The importance of addressing these weaknesses needs to be underscored as these all pertain to services that the Academy should provide to the employees and students.

In terms of the indicators having the lowest ratings which were perceived as institutional weaknesses, quality of classrooms and laboratories garnered the lowest rating of 2.69. PMMA has two (2) academic buildings: the College of Marine Transportation and College of Marine Engineering buildings. The rooms are not all air conditioned but ventilated with electric fans, though the number of these fans would not be enough for the size of class accommodating the rooms. In addition, each room has a monitor and CPU installed to make classes more interactive and creative, although some units have missing accessories like remote control and adaptors. On the other hand, PMMA has the following laboratories: Chemistry laboratory, machine shop, Physics laboratories, AR/VR room, engineering room simulator, Global Maritime Distress and Safety System (GMDSS), Electronic Chart Display and Information System (ECDIS), and computer laboratories to provide cadets a hands-on experience of theoretical discussions. Although these classrooms and laboratories are present, the respondents perceived that the quality can be enhanced through some of the recommendations of the cadets like repainting of classrooms and provision of better classroom facilities. Regarding the adequacy of classrooms and laboratories, with 2.71 mean score, which is one of the weaknesses of the Academy, it was stated in the study of Selvitopu and Kaya (2020) that one point of weaknesses is about infrastructure which most of Turkish universities stated in their SWOTs which, like in PMMA, includes the quality and inadequacy of classrooms and laboratories. The Academy has a laboratory but it is rarely being used by the cadets for it lacks apparatus and equipment. The number of classrooms in the two colleges became insufficient when the implementation of limited face-to-face classroom instruction began. The Academy needs to comply with the Inter-Agency Task Force (IATF) Protocols, so only 20 cadets can be accommodated in each classroom to maintain physical distancing. The current maximum 20:1 ratio of cadets per classroom, which was 20-24:1 before, has required additional classrooms in the Academy.

Accordingly, availability of financial aid for qualified students got one of the lowest ratings with 2.69. As a state university, students of PMMA enjoy free tuition and other school 
fees as provided by Republic Act (RA) No. 10931, otherwise known as the Universal Access to Quality Tertiary Education Act. For SY 2020 - 2021. A total of 916 and 903 cadets during the first semester and second semester were qualified for this respectively. In addition, 42 cadets for Tertiary Education Subsidy (TES) Listahanan and 4 cadets for TES Tulong-Dunong Program were eligible for the CHED UniFAST scholarship.

However, aside from the tuition fee, the cadets/cadettes that enroll at PMMA need to pay for miscellaneous fees such as uniform, haircut, and laundry which range from Php 16,561.60 up to Php 32,783.85 for First Semester, SY 2020 - 2021. Thus, although tuition is free, there are cadets who struggle to pay for the miscellaneous fees. Providing free miscellaneous and other fees to deserving students would inspire and motivate them to do better in their studies. Liu (2019) strongly recommended that diverse ways to motivate students and stimulate their inner development should be reconsidered and explored. There should be more projects that are inspiring and motivating to students, especially to those who are outstanding in academics, sports, skills and voluntary services. Furthermore, as policy makers, governments and schools must be determined and enforceable to face and change the issue of student aids.

The Mess Hall is where the food is served and cadets eat together. The mess services ranked 3 as weakness perceived by the respondents. With the mean score of 2.70 , most of the respondents agreed that the service in terms of tangibility is not satisfactory. This led them to recommend cleanliness of the mess hall including the utensils and food preparation and improvement in the variety of food.

The use of simulators in Maritime Education and Training is a vital component for developing seafarer competencies. Developed immersive technologies such as virtual reality (VR), augmented reality (AR) and mixed reality (MR) have created new and different possibilities for maritime education. The adoption and integration of these technologies into the education, training, and operations of maritime industries provide new possibilities and paradigms to support operators and operations both on land and at sea. (Mallam et al., 2019) However, the Commission on Audit has observed certain failures in the simulators delivered in the academy. This implies that the supposed state-of-the-art equipment cannot be fully utilized by the students to hone their practical skills, making this an institutional weakness of the Academy with 2.75 mean. (coa.gov.ph)

\section{Perceived Distinct Excellence of PMMA}

In terms of PMMA's distinct excellence, Table 2 shows that majority of the respondents agree that PMMA is distinctly excellent in different areas: management style, quality of education, training programs, research and development, student support services/programs, shipboard training program, and networking/partnership with external stakeholders. Shipboard Training Program got the highest rating of 3.22 which supports the identified strengths (Rank 1) and potential opportunities (Rank 1). According to Fan (2020), the Philippines is now the world's largest supplier of management-level seafarers; and its seafarers are generally well received and well regarded around the world. In the course of their seafarers' training, the school and enterprise work closely together, and a special on-board training session has been set up.

\section{Potential Opportunities}

Table 3 presents the eleven (11) potential opportunities to assess the conditions or situations that are considered to have positive impact. The respondents placed the 
partnership with shipping companies as rank one (1). This is evident with the trust elicited by the forty-eight (48) partner shipping companies of the Academy. Also, the result describes that the respondents consider accreditation/membership to international maritime organization/s, improvements in the maritime industry, demand for international seafarers, and reputation of PMMA in the maritime industry as opportunities. Clearly, despite the COVID-19's spread, "Filipinos remain to be preferred by foreign shipowners and principals." This was attested by the Maritime Industry Authority (Marina) Administrator Robert Empedrad. Just by the sheer volume of the Filipino seafarers sailing international waters, there is no question why the Philippines is a maritime giant dubbed as the manning capital of the world. (Cruz, 2021)

\section{Potential Threats}

As seen in Table 4, the result shows that most of the respondents agreed that the Academy has threats related to the ongoing COVID-19 pandemic/other future health crisis. The COVID-19 pandemic has created the largest disruption of education systems in history, affecting nearly 1.6 billion learners in more than 190 countries and all continents. (United Nations Sustainable Development Group, 2020) The rapid spread of COVID-19 pandemic has had a major impact on global shipping markets (Oshavillo, 2020). This is evident with the highest mean of 3.04.

Dr. Tedros Adhanom Ghebreyesus, WHO Director-General said that, "Schools play a vital role in the well-being of students, families and their communities, and the link between education and health has never been more evident" (World Health Organization, 2021). The ongoing COVID-19 and other future health crisis ranked one as threat faced by the Academy, as it experienced its peak to 309 COVID-19 cases in the month of May 2021 (Paraggua, et al., 2021).

Another threat about which the majority of the respondents agreed were partnership with shipping companies, reputation of the PMMA in the maritime industry, government regulation, and lack of financial support for qualified students who passed the PMMA admission process. Since the Academy is supported only by government funds with help from the shipping industry, financial support might be insufficient to assist all the educational needs of the qualified students of the Academy. PMMA is regarded as the pioneer institution in maritime education in the country, and this reputation poses threat and challenge to the Academy due to the existence of other maritime institutions in the Philippines.

It is important to note that there were two areas identified by the respondents as both an opportunity and a threat, namely Partnership with Shipping Companies and Reputation of PMMA in the Maritime Industry. Good reputation would lead to great opportunities. PMMA, holding public pride in the maritime industry, attracts various shipping companies which demand for more competent graduates from the Academy. The good name of PMMA also results in a more solid partnership with top international shipping companies that offer effective training to the cadets and possible employment to the PMMA graduates. Reputation would also bring threats to the academy once the good name is destroyed and this would lead to lack of trust from the stakeholders. When this happens, there will be lesser cadet applicants and fewer partnerships with shipping companies.

\section{CONCLUSION}


Carrying out a SWOT analysis is relevant for the implementation of strategic planning. The SWOT Analysis reveals that the aims of the Academy for utmost customer satisfaction and compliance to all requirements and guidelines were perceived as strengths. The partnership with shipping companies is considered the most prominent as Academy's asset. The deployment of midshipmen for shipboard training was unfazed by the pandemic (Abutal, 2021).

On the other hand, there still exist some weaknesses. While finite resources are always a factor in addressing weaknesses or threats, it should not be assumed that the reason for the weakness or threat is due to finite resources. Institutions make resource allocation decisions continuously and prioritize how and whether to address certain strategic priorities. In addressing strategic priorities, it will be important for the Academy to address the core issues and not just assume it is a resource problem. The Academy may propose and request additional funds for the improvement of the state-of-the-art facilities, adequacy, and quality of classrooms and laboratories. Trainings and workshops for using simulators, AVR, and other equipment for the faculty are also encouraged. The Academy may also seek assistance and sponsorship for financial aid for qualified students. Also, the quality operation procedure of the Mess Unit should be reviewed as mess services were perceived as weakness. In addition, the Strategic Planning Committee may help set overall goals for these identified weaknesses and develop a plan to achieve them.

For the opportunities, the Academy should explore advantages despite the pandemic and competition in the maritime industry. At the same time, much attention has to be given to the threats confronting the Academy.

SWOT analysis is an essential part of the strategic planning process to help institutions to understand their strengths, weaknesses, opportunities, and threats. For PMMA to face the challenges brought by globalization and to withstand the obstacles to the maritime industry brought by the pandemic, the Academy has to develop a responsive strategic planning approach, and SWOT should be the first systematic attempt to establish strategic planning. Institutional leaders and their planning partners now have to think and plan strategically. In the context of the rapidly changing world, this will be a prerequisite for any organizational survival and prosperity.

Finally, this SWOT Analysis provides an essential baseline of the feedback received from the employees and students that concisely targets issues to be addressed in the PMMA Strategic Plan and operationalize that plan. In the end, recognizing strengths and weaknesses, and factoring opportunities and threats into concrete actions through the strategic planning process will help PMMA in its continuous pursuit on the premier maritime institution.

\section{REFERENCES}

Abutal, J. (2020). Superintendent's Corner. Philippine Merchant Marine Academy. Retrieved 9 December 2021, from https://www.pmma.edu.ph/.

Adepoju, T., \& Okunola, P. (2018). The Application of Strengths, Weaknesses, Opportunities and Threats (SWOT) Analysis for Managing Vocational and Technical Education (VTE) Programmes for Improved Efficiency in Nigeria. Educational Research and Reviews, 5(7). https://globaledunet.org/wpcontent/uploads/2018/09/Paper-2-Okunola.pdf 
Aisyi, G., \& Zulkarnain, L. (2020). SWOT Analysis in an Educational Institution (Case Study: Baitul Qur'an Islamic Boarding School, Depok). Jurnal Ekonomi Dan Perbankan Syariah, 8(1). https://doi.org/10.46899/jeps.v8i1.177

Amos, N. B., Dogo, E. B., Egwakhe, J. A., \& Umukoro, J. E. (2021). Operational Resilience and Efficiency of Private Universities in Southwest Nigeria: The COVID-19 Pandemic Experience. Journal of Business and Entrepreneurship, $10(1)$, $1-14$. https://ojs.sampoernauniversity.ac.id/index.php/JOBE/article/view/203/125

Apriyani, R., Bandono, A., Purnomo, J., \& S. (2019). Development Strategy of Education Curriculum in STTAL. International Journal of ASRO, 10(3), 99-104. http://asrojournal-sttal.ac.id/index.php/ASRO/article/view/165/120

Campara, L., Francic, V., \& Bupic, M. (2017). Quality of maritime higher education from seafarers' perspective. Scientific Journal of Maritime Research, 31(2). https://doi.org/10.31217/p.31.2.8

Cruz, R. (2021, December 10). Still preferred! Maritime veterans explain why Filipinos are still no. 1. The Manila Times. https://www.manilatimes.net/2021/06/25/supplements/still-preferred/1804511

Fan, L. (2020). Research on the method of seafarers' competence assessment in China based on Delphi Method and Swot Analysis. Maritime Commons: The Digital Repository of the World Maritime University. https://commons.wmu.se/cgi/viewcontent.cgi?article= 1286\&context=msem_dissertations

George, B., Walker, R. M., \& Monster, J. (2019). Does Strategic Planning Improve Organizational Performance? A Meta-Analysis. Public Administration Review, 79(6), 810-819. https://doi.org/10.1111/puar.13104

Gurel, E., \& Tat, M. (2017). SWOT Analysis: A Theoretical Review. The Journal of International Social Research, 10(51). https://doi.org/10.17719/jisr.2017.1832

International Maritime Organization. (2019). Women in Maritime. IMO. https://www.imo.org/en/OurWork/TechnicalCooperation/Pages/WomenInMariti me.aspx

Jackson, T. (2021, September 27). Strategic Planning: The Ultimate Guide To Preparing, Creating, \& Deploying Your Strategy. ClearPoint Strategy. Retrieved October 28, 2021, from https://www.clearpointstrategy.com/strategic-planning-ultimateguide/

Khalid, J., Ali, A., Khaleel, M., Islam, M., \& Shu, Q. (2017). Towards Global Knowledge Society; A SWOT Analysis of Higher Education of Pakistan in Context of Internationalization. Journal of Business, 2(2). https://doi.org/10.18533/job.v2i2.65 
Liu, J. (2019). A Quantitative Study on Student Financial Aid of a Local Undergraduate College in China. World Journal of Education, 9(6). https://files.eric.ed.gov/fulltext/ EJ1235340.pdf

Mallam, S., Nazir, S., \& Renganayagalu, S. (2019). Rethinking Maritime Education, Training, and Operations in the Digital Era: Applications for Emerging Immersive Technologies. Journal of Marine Science and Engineering, 7, 428. https://doi.org/10.3390/jmse7120428

Oshavillo, G. (2020). A Paradigm Shift of Learning in Maritime Education amidst COVID-19 Pandemic. International Journal of Higher Education, 9(6), 164-177. https://files.eric.ed.gov/fulltext/EJ1277930.pdf

Paraggua et.al (2021).Conquering the Stormy Seas of the Pandemic: Appropriateness and Effectiveness of Covid-19 Response in a Maritime Quasi-Military Institution. Department of Research, Development and Extension, Philippine Merchant Marine Academy.

Pratt,

M. (2016, August).

Techtarget.https://searchcio.techtarget.com/ definition/strategic-planning

Selvitopu, A., \& Kaya, M. (2020). Looking Inside the Strategic Plans: Strengths and Weaknesses of Turkish Higher Education Institutions. Qualitative Research in Education, 9(1), 32. https://doi.org/10.17583/qre.2020.4111

Shvardak, M. (2021). SWOT-Analysis as a Strategic Management Tool of the Quality Training of the Future Educational Institution Head. Ilkogretim Online Elementary Education Online, 20(1), 958-967. https://doi.org/10.17051/ilkonline.2021.01.96

Tuncay, M. (2015). SWOT Analysis in Strategic Management and a Sample Application in Public. International Research Journal of York University, 2(3), 276-301. https://mpra.ub.uni-muenchen.de/67213/

Wang, X., Li, M., \& Cao, J. (2018, June). SWOT Analysis of the Old and New Campus of the University and Its Countermeasures. Advances in Social Science, Education and Humanities Research, Proceedings of the 2018 2nd International Conference on Education, Economics and Management Research (ICEEMR 2018). https://doi.org/10.2991/iceemr-18.2018.81

White, S. (2018, December 19). What is SWOT analysis? A strategic tool for achieving objectives. CIO from IDG. https://www.cio.com/article/3328853/swot-analysisdefined.html

World Health Organization. (2021, June 22). UNESCO and WHO urge countries to make every school a health-promoting school. WHO. 
https://www.who.int/news/item/22-06-2021-unesco-and-who-urge-countries-tomake-every-school-a-health-promoting-school

United Nations Sustainable Development Group. (2020, August). 2 POLICY BRIEF: EDUCATION DURING COVID-19 AND BEYOND. UNSDG. https://unsdg.un.org/resources/policy-brief-education-during-covid-19-andbeyond

Vitan, D. (2017). The SWOT Analysis of Pre-university Education. "Ovidius" University Annals, 